\title{
Tissue Slice Technology
}

National Cancer Institute

\section{Source}

National Cancer Institute. Tissue Slice Technology. NCI Thesaurus. Code C19286.

A technology used for preclinical research as an alternative to some animal testing.

Micrometer-thin slices of various organs are incubated with various experimental

compounds for assays involving toxicology, absorption, distribution, and metabolism. 